\title{
PEMANFAATAN TUMBUHAN OBAT OLEH MASYARAKAT SUKU MELAYU DI DESA SUNGAI DAUN KECAMATAN SELAKAU KABUPATEN SAMBAS
}

\author{
Lili Meisia $^{\mathbf{1}}$, Rafdinal ${ }^{1}$, Siti Ifadatin ${ }^{1}$ \\ ${ }^{1}$ Program Studi Biologi, Fakultas MIPA, Universitas Tanjungpura, Pontianak \\ Email korespondensi: $\underline{\text { lilimeisia5@gmail.com }}$
}

\begin{abstract}
The Malay Tribe in West Kalimantan are the largest after Dayak Tribe. The most people in Sungai Daun Village are Malay Tribe who still use plants as medicine. This research was conducted with the aim to know the types of medicinal plants, parts of plants used as medicines and methods of processing and the use of plants as medicine. The research was conducted in Sungai Daun Village, Selakau Sub-District, Sambas District. The research method using snowball sampling with 12 respondents consist of village heads, herbalist, shaman giving birth and other community members who have knowledge about medicinal plants. The results showed that there were 74 species of plants included in the 43 families used as medicine. The highest percentage of families is Asteraceae (6,8\%), Euphorbiaceae (6,8\%) and Piperaceae (6,8\%). Part of a widely used plant as medicine is the leaves $(48,8 \%)$, while the way of processing and the use of medicinal plants is in boiled $(55,3 \%)$ and drunk $(48,3 \%)$.
\end{abstract}

Keywords: Medicinal Plants, Malay Tribe, Sungai Daun Village

\section{PENDAHULUAN}

Suku Melayu di Kalimantan Barat adalah suku terbesar setelah Suku Dayak (Ahyat, 2005). Suku Melayu banyak tersebar di pesisir diantaranya adalah di Kabupaten Sambas. Suku Melayu di Desa Sungai Daun merupakan bagian dari Melayu Sambas. Suku Melayu di Desa Sungai Daun memiliki tradisi dalam mengelola dan memanfaatkan tumbuhan, salah satunya adalah tumbuhan obat.

Penelitian mengenai pemanfaatan tumbuhan sebagai obat telah banyak dilakukan. Hasil penelitian Sari et al (2014) di Dusun Serambi Kecamatan Kembayan Kabupaten Sanggau menemukan 35 famili dan 51 jenis tumbuhan obat. Hasil penelitian Gunadi et al (2017) di Desa Gerantung Kecamatan Monterado Kabupaten Bengkayang menemukan 36 famili dan 51 jenis tumbuhan obat. Hasil penelitian Sudarmono (2018) di Desa Subah Kabupaten Sambas menemukan 19 famili dan 30 jenis tumbuhan obat. Hasil penelitian Indra et al (2014), beberapa tumbuhan obat yang biasa dimanfaatkan oleh masyarakat Suku Melayu yaitu pepaya (Carica papaya L.) untuk mengobati demam, kembang sepatu (Hibiscus rosa-sinensis) untuk mengobati mag, melati putih (Jasminum sambac Ait.) untuk mengobati BAB (Buang Air Besar) berdarah, katuk (Sauropus androgynus L.) untuk mengobati bengkak dan memperbanyak ASI, seledri (Apium graveolens $\mathrm{L}$.) untuk mengobati rematik, ciplukan (Physallis perwiana L.) untuk mengobati masuk angin, kelapa ( Cocos nucifera L.) sebagai penawar racun, dan sirih (Piper betle L.) untuk mengobati sakit kepala, sakit gigi dan juga gatalgatal. Pengolahan tumbuhan obat ini masih menggunakan cara yang sederhana seperti ditumbuk, direbus, dan diremas.

Suku Melayu di Desa Sungai Daun menggunakan tumbuhan obat untuk penyembuhan berbagai macam penyakit karena mudah didapatkan, bahan bakunya dapat ditanam di pekarangan rumah maupun di kebun, dapat diramu sendiri dan cara pengolahannya masih sangat sederhana. Namun diantara berbagai jenis tumbuhan obat sebagian besar tidak diketahui oleh masyarakat setempat sehingga tidak dirawat dan dilestarikan dengan baik. Hal ini menyebabkan masyarakat tidak mengenal jenis-jenis tumbuhan obat dan tumbuhan obat terkesan sebagai tumbuhan liar yang keberadaannya mengganggu tumbuhan lain atau sebagai gulma. Selain itu kawasan desa tersebut juga terjadi pembukaan lahan perkebunan kelapa, kelapa sawit, karet, pisang dan ladang pertanian sehingga berdampak pada berkurangnya tumbuhan obat yang ada di sekitar kawasan tersebut, sehingga perlu adanya upaya pelestarian tumbuhan obat.

Tujuan dari penelitian ini adalah mengetahui jenis-jenis tumbuhan yang digunakan sebagai obat, jenis penyakit yang dapat disembuhkan, bagian tumbuhan yang digunakan sebagai obat 
dan cara pengolahan dan penggunaan tumbuhan yang digunakan sebagai obat oleh masyarakat Suku Melayu.

\section{BAHAN DAN METODE}

\section{Waktu dan Tempat}

Penelitian ini dilakukan selama 4 bulan, dimulai dari bulan Mei sampai Agustus 2019 di Desa Sungai Daun Kecamatan Selakau Kabupaten Sambas Provinsi Kalimantan Barat. Identifikasi tumbuhan obat dan pengolahan data dilakukan di Laboratorium Biologi Fakultas Matematika dan Ilmu Pengetahuan Alam Universitas Tanjungpura, Pontianak.

\section{Deskripsi Lokasi}

Sungai Daun merupakan sebuah desa yang terletak di Kecamatan Selakau, Kabupaten Sambas, Provinsi Kalimantan Barat (Gambar
1).Desa Sungai Daun memiliki luas sekitar $17.136 \mathrm{~km}^{2}$. Penduduk di Desa Sungai Daun terdiri dari $1102 \mathrm{KK}$ (Kepala Keluarga) dengan laki-laki sebanyak 2081 orang dan perempuan sebanyak 1829 orang. Jumlah keseluruhan penduduk di Desa Sungai Daun adalah 3.910 orang (Badan Pemberdayaan Masyarakat dan Pemerintahan Desa, 2014).

Jumlah penduduk Suku Melayu di Desa Sungai Daun adalah 3413 orang (87, 29 \%). Selain Suku Melayu terdapat juga suku lainnya yaitu Suku Bugis 15 orang $(0,38 \%)$, Suku Cina 431 orang $(11,02 \%)$, Suku Jawa 38 orang $(0,97 \%)$, Suku Dayak 11 orang $(0,28 \%)$, Suku Batak 1 orang $(0,3 \%)$ dan Suku Padang 1 orang $(0,3 \%)$. Sebagian besar masyarakat Desa Sungai Daun bermata pencaharian di bidang pertanian, perkebunan dan swasta (Badan Pemberdayaan Masyarakat \& Pemerintahan Desa, 2014).

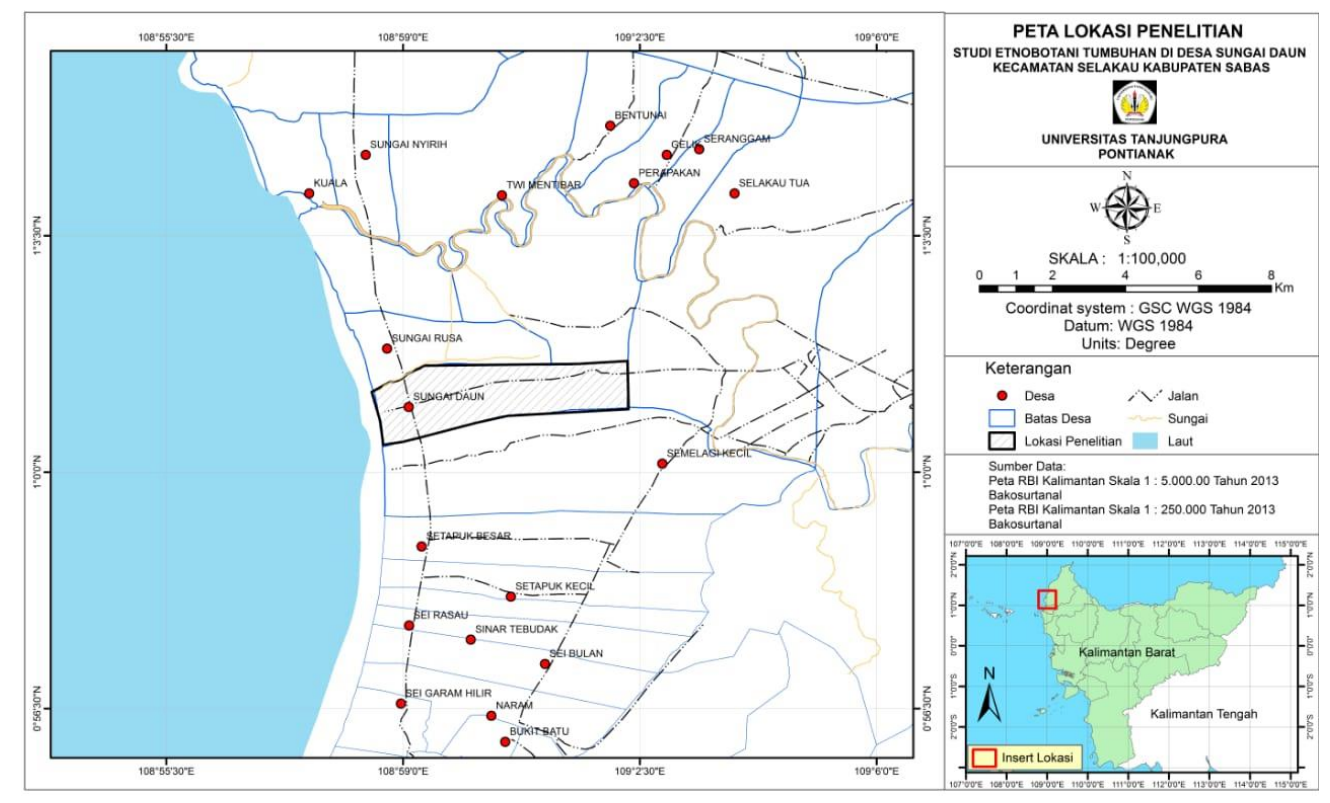

Gambar 1. Peta Lokasi Desa Sungai Daun

\section{Alat dan Bahan}

Alat dan bahan yang digunakan dalam penelitian ini adalah alat tulis, alat perekam suara, benang, buku identifikasi tumbuhan, gunting, jarum, kertas label, karton, kardus, kuesioner, kamera, parang/pisau, plastik, selotif bening, sprayer, sasak bambu $50 \mathrm{~cm}$ dan alkohol $70 \%$.

\section{Pelaksanaan Penelitian}

Penentuan responden menggunakan metode teknik snowball sampling (Bernard, 2004). Responden terdiri dari kepala desa, dukun kampung, dukun beranak dan anggota masyarakat lainnya yang memiliki pengetahuan mengenai tumbuhan obat. Jumlah responden yang diwawancarai di Desa Sungai Daun Kecamatan Selakau Kabupaten Sambas berjumlah 12 orang. Tahapan penelitian ini adalah observasi, pengumpulan data, pengambilan sampel tumbuhan obat, pembuatan herbarium tumbuhan obat dan identifikasi tumbuhan obat yang berpedoman pada buku "Flora" (Steenis et al., 2005), "Atlas Tumbuhan Obat Indonesia Jilid 1" (Dalimartha, 1999), buku "Tumbuhan Obat Taman Nasional Gunung Halimun, Jawa Barat, Indonesia" (Harada et al., 2006), buku "Tumbuhan Obat Tradisional di Sulawesi Utara Jilid I" (Kinho et al., 2011), dan buku"Tumbuhan Obat Tradisional di Sulawesi Utara Jilid II" (Kinho et al., 2011). Data yang terkumpul kemudian dianalisis secara deskriptif. 


\section{HASIL DAN PEMBAHASAN}

\section{Hasil}

Berdasarkan penelitian pemanfaatan tumbuhan obat oleh masyarakat Suku Melayu di Desa Sungai Daun diperoleh 74 jenis tumbuhan yang termasuk ke dalam 43 famili yang digunakan sebagai obat (Tabel 1). Persentase famili terbesar adalah famili Asteraceae, Euphorbiaceae dan Piperaceae $(6,8 \%)$ (Gambar 2). Cara pengolahan dan penggunaan tumbuhan obat oleh masyarakat Desa Sungai Daun tergantung dari jenis tumbuhan yang digunakan sebagai obat dan jenis penyakit yang disembuhkan. Sebagian besar tumbuhan obat diperoleh langsung di pekarangan rumah.

Tabel 1. Famili dan Jenis Tumbuhan Obat yang digunakan oleh Masyarakat Suku Melayu di Desa Sungai Daun Kecamatan Selakau Kabupaten Sambas

\begin{tabular}{|c|c|c|c|c|c|c|}
\hline No & $\begin{array}{l}\text { Famili dan Jenis } \\
\text { Tumbuhan Obat }\end{array}$ & $\begin{array}{c}\text { Nama } \\
\text { Daerah }\end{array}$ & Habitus & $\begin{array}{c}\text { Bagian } \\
\text { Tumbuhan }\end{array}$ & $\begin{array}{l}\text { Cara Pengolahan/ } \\
\text { Penggunaan }\end{array}$ & Kegunaan \\
\hline 1 & 2 & 3 & 4 & 5 & 6 & 7 \\
\hline 1. & $\begin{array}{l}\text { Acanthaceae } \\
\text { Graptophyllum } \\
\text { pictum (L.) Griff. }\end{array}$ & Puding & Perdu & Daun & Direbus/ Diminum & $\begin{array}{c}\text { Kolesterol, darah } \\
\text { tinggi }\end{array}$ \\
\hline 2. & $\begin{array}{l}\text { Amaranthaceae } \\
\text { Celosia argentea } \\
\text { L. }\end{array}$ & $\begin{array}{l}\text { Jengger } \\
\text { Ayam }\end{array}$ & Herba & Bunga & Direbus/ Diminum & Batuk \\
\hline 3. & $\begin{array}{l}\text { Annonaceae } \\
\text { Annona muricata } \\
\text { L. }\end{array}$ & $\begin{array}{l}\text { Nangka } \\
\text { belande }\end{array}$ & Pohon & Daun & Direbus/ Diminum & $\begin{array}{c}\text { Kolesterol, darah } \\
\text { tinggi }\end{array}$ \\
\hline \multirow[t]{3}{*}{4.} & $\begin{array}{l}\text { Apiaceae } \\
\text { Apium graveolens } \\
\text { L. }\end{array}$ & Daun sop & Herba & Daun & Direbus/ Dimakan & Darah tinggi, rematik \\
\hline & $\begin{array}{l}\text { Centella asiatica } \\
\text { (L.) Urban }\end{array}$ & Pegage & Herba & Daun & Ditumbuk/ Ditempelkan & Luka luar \\
\hline & & & & & Direbus/ Dimakan & darah tinggi \\
\hline 5. & $\begin{array}{l}\text { Apocynaceae } \\
\text { Catharantus } \\
\text { roseus (L.) G. } \\
\text { Don }\end{array}$ & $\begin{array}{l}\text { Tapak } \\
\text { dara }\end{array}$ & Herba & Daun & Direbus/ Diminum & Kencing manis \\
\hline \multirow[t]{2}{*}{6.} & $\begin{array}{l}\text { Arecaceae } \\
\text { Areca cathecu L. }\end{array}$ & Pinang & Pohon & Air buah & Dipotong/ Dimandikan & $\begin{array}{c}\text { Mengurangi } \\
\text { pendarahan saat haid, } \\
\text { sakit perut } \\
\text { Gatal-gatal }\end{array}$ \\
\hline & & & & & Dipotong/ Diminum & Keracunan \\
\hline \multirow[t]{6}{*}{7.} & $\begin{array}{l}\text { Asteraceae } \\
\text { Gynura } \\
\text { procumbens L. } \\
\text { Merr }\end{array}$ & $\begin{array}{c}\text { Sambung } \\
\text { nyawa }\end{array}$ & Perdu & Daun & Direbus/ Diminum & $\begin{array}{c}\text { Kolesterol, darah } \\
\text { tinggi }\end{array}$ \\
\hline & $\begin{array}{l}\text { Ageratum } \\
\text { conyzoides L. }\end{array}$ & Kalimao & Herba & Daun & Ditumbuk/ Dibalurkan & Demam \\
\hline & & & & & Diperas/ Diminum & Sakit perut \\
\hline & $\begin{array}{l}\text { Cosmos caudatus } \\
\text { Kunth }\end{array}$ & Keniker & Perdu & Daun & Direbus/ Diminum & Obat dalam \\
\hline & $\begin{array}{l}\text { Vernonia cinerea } \\
\text { (L.) Less. }\end{array}$ & Kedaraan & Herba & $\begin{array}{l}\text { Batang, } \\
\text { akar, daun, } \\
\text { bunga }\end{array}$ & Ditumbuk/ Ditempelkan & Demam \\
\hline & $\begin{array}{l}\text { Thitonia } \\
\text { diversifolia } \\
\text { (Hemsley) A. } \\
\text { Gray }\end{array}$ & $\begin{array}{l}\text { Bunge } \\
\text { insulin }\end{array}$ & Perdu & Daun & Direbus/ Diminum & Kencing manis \\
\hline
\end{tabular}


Lanjutan Tabel 1. Famili dan Jenis Tumbuhan Obat yang digunakan oleh Masyarakat Suku Melayu di Desa Sungai

\begin{tabular}{|c|c|c|c|c|c|c|}
\hline \multicolumn{6}{|c|}{ Daun Kecamatan Selakau Kabupaten Sambas } & \multirow[b]{2}{*}{7} \\
\hline 1 & 2 & 3 & 4 & 5 & 6 & \\
\hline \multirow[t]{3}{*}{8.} & Basellaceae & & & & & \\
\hline & $\begin{array}{l}\text { Anredera } \\
\text { cordifolia (Ten.) }\end{array}$ & $\begin{array}{l}\text { Minohon } \\
\mathrm{g}\end{array}$ & Liana & Daun & Diperas/ Dioleskan & Bisul, \\
\hline & Steenis & & & & Direbus/ Diminum & Tambah darah \\
\hline 9. & $\begin{array}{l}\text { Campanulaceae } \\
\text { Isotoma } \\
\text { longiflora (L.) C. } \\
\text { Presl }\end{array}$ & Katarak & Herba & Daun & Diperas/ Diteteskan & Sakit mata \\
\hline \multirow[t]{2}{*}{10.} & $\begin{array}{l}\text { Caricaceae } \\
\text { Carica papaya L. }\end{array}$ & Batek & Perdu & Daun & Direbus/ Dimakan & Demam, malaria \\
\hline & & & & Getah & Dipotong/ Dioleskan & Kutil \\
\hline 11. & $\begin{array}{l}\text { Clusiaceae } \\
\text { Mangostana } \\
\text { garcinia Gaertn. }\end{array}$ & Manggis & Pohon & Kulit Buah & Direbus/ Diminum & $\begin{array}{l}\text { Kolesterol, kanker, } \\
\text { darah tinggi }\end{array}$ \\
\hline \multirow[t]{2}{*}{12.} & $\begin{array}{l}\text { Commelinaceae } \\
\text { Rhoeo discolor } \\
\text { (L.) Hance }\end{array}$ & $\begin{array}{l}\text { Pandan } \\
\text { ungu }\end{array}$ & Herba & Daun & Direbus/ Diminum & Ginjal \\
\hline & $\begin{array}{l}\text { Zebrina pendula } \\
\text { Schinitz. }\end{array}$ & Zebrina & Herba & Daun & Ditumbuk/Ditempelkan & Bengkak \\
\hline 13. & $\begin{array}{l}\text { Crassulaceae } \\
\text { Calanchoe } \\
\text { pinnata (Lam.) }\end{array}$ & $\begin{array}{l}\text { Tumbuh } \\
\text { daun }\end{array}$ & Herba & Daun & Ditumbuk/ Ditempelkan & Demam \\
\hline \multirow[t]{5}{*}{14.} & $\begin{array}{l}\text { Pers. } \\
\text { Euphorbiaceae } \\
\text { Sauropus } \\
\text { androgynus (L.) } \\
\text { Merr. }\end{array}$ & $\begin{array}{l}\text { Cangkok } \\
\text { manis }\end{array}$ & Perdu & Daun & Direbus/ Dimakan & $\begin{array}{l}\text { Melancarkan ASI, } \\
\text { maag }\end{array}$ \\
\hline & $\begin{array}{l}\text { Phyllanthus niruri } \\
\text { L. }\end{array}$ & Meniran & Herba & $\begin{array}{c}\text { Batang, } \\
\text { akar, daun, } \\
\text { buah }\end{array}$ & Direbus/ Diminum & $\begin{array}{c}\text { Peluruh air seni, sakit } \\
\text { persendian }\end{array}$ \\
\hline & $\begin{array}{l}\text { Manihot esculenta } \\
\text { Crantz }\end{array}$ & Bandong & Perdu & Daun & Ditumbuk/ Ditempelkan & Sakit perut \\
\hline & $\begin{array}{l}\text { Acalypha hispida } \\
\text { Burm. f. }\end{array}$ & $\begin{array}{l}\text { Ekor } \\
\text { kucing }\end{array}$ & Perdu & Daun & Direbus/ Diminum & Sariawan, batuk \\
\hline & $\begin{array}{l}\text { Codiaeum } \\
\text { variegatum } \mathrm{L} .\end{array}$ & Puring & Perdu & Daun & Ditumbuk/ Ditempelkan & Sakit perut \\
\hline 15. & $\begin{array}{l}\text { Elaeocarpaceae } \\
\text { Muntingia } \\
\text { calabura L. }\end{array}$ & Ceri & Pohon & Daun & Direbus/ Diminum & $\begin{array}{c}\text { Jantung, kanker, } \\
\text { kolesterol }\end{array}$ \\
\hline \multirow[t]{2}{*}{16.} & $\begin{array}{l}\text { Fabaceae } \\
\text { Tamarindus } \\
\text { occidentalis } \\
\text { Gaertn. }\end{array}$ & $\begin{array}{l}\text { Asam } \\
\text { jawe }\end{array}$ & Pohon & Buah & Direbus/ Diminum & Batuk \\
\hline & Cassia alata $\mathrm{L}$. & $\begin{array}{l}\text { Gelingga } \\
\mathrm{ng}\end{array}$ & Perdu & Daun & Diperas/ Dioleskan & Panu, kurap \\
\hline 17. & $\begin{array}{l}\text { Iridaceae } \\
\text { Eleutherine } \\
\text { americana Merr. }\end{array}$ & $\begin{array}{l}\text { Bawang } \\
\text { mekah }\end{array}$ & Herba & Umbi & Direbus/ Diminum & Kanker, kista \\
\hline 18. & $\begin{array}{l}\text { Lamiaceae } \\
\text { Orthosiphon } \\
\text { aristatus ( Blume) } \\
\text { Miquel }\end{array}$ & $\begin{array}{l}\text { Somet } \\
\text { kucing }\end{array}$ & Semak & Daun & Direbus/ Diminum & Sakit persendian \\
\hline
\end{tabular}


Lanjutan Tabel 1. Famili dan Jenis Tumbuhan Obat yang digunakan oleh Masyarakat Suku Melayu di Desa Sungai

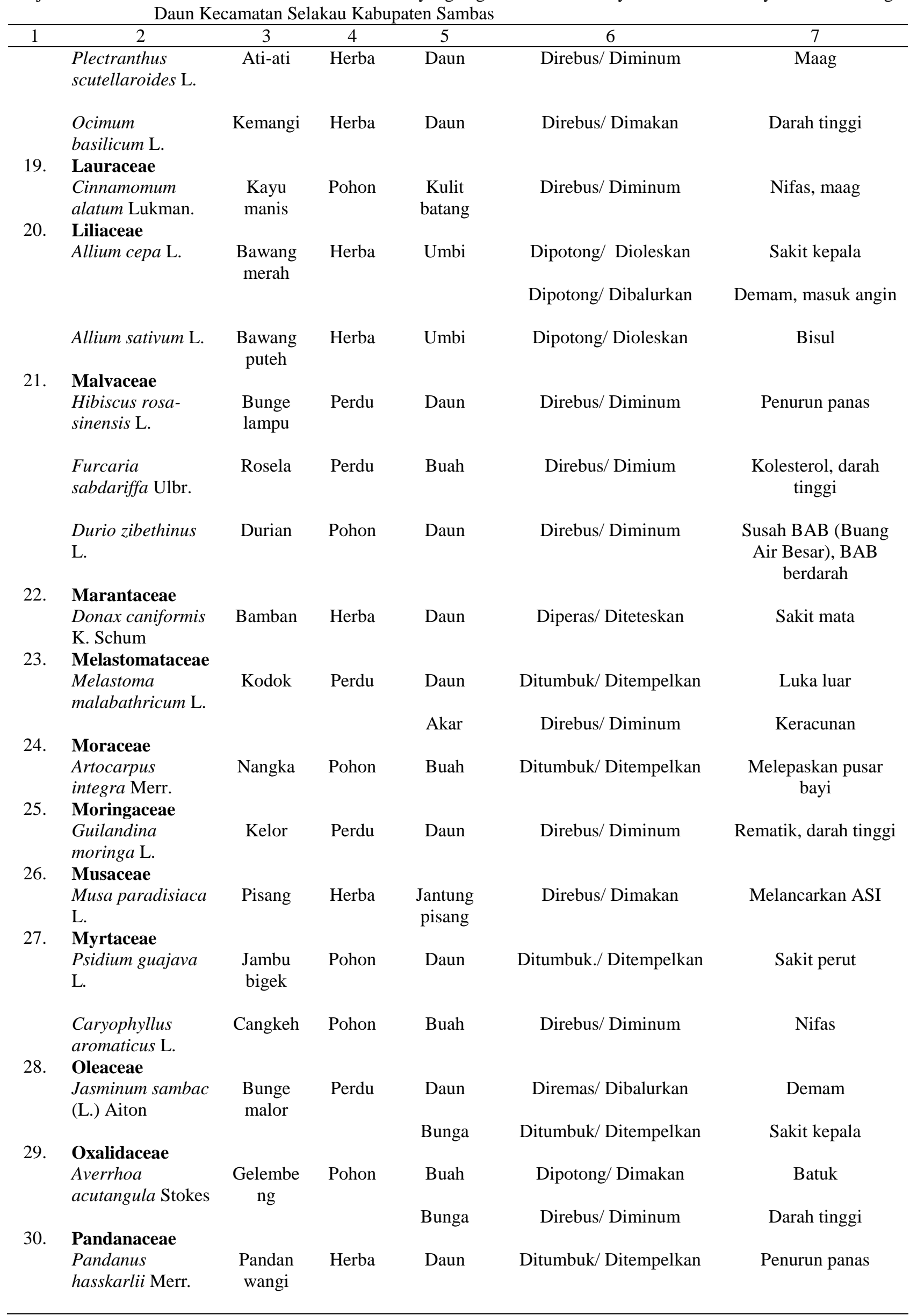


Lanjutan Tabel 1. Famili dan Jenis Tumbuhan Obat yang digunakan oleh Masyarakat Suku Melayu di Desa Sungai

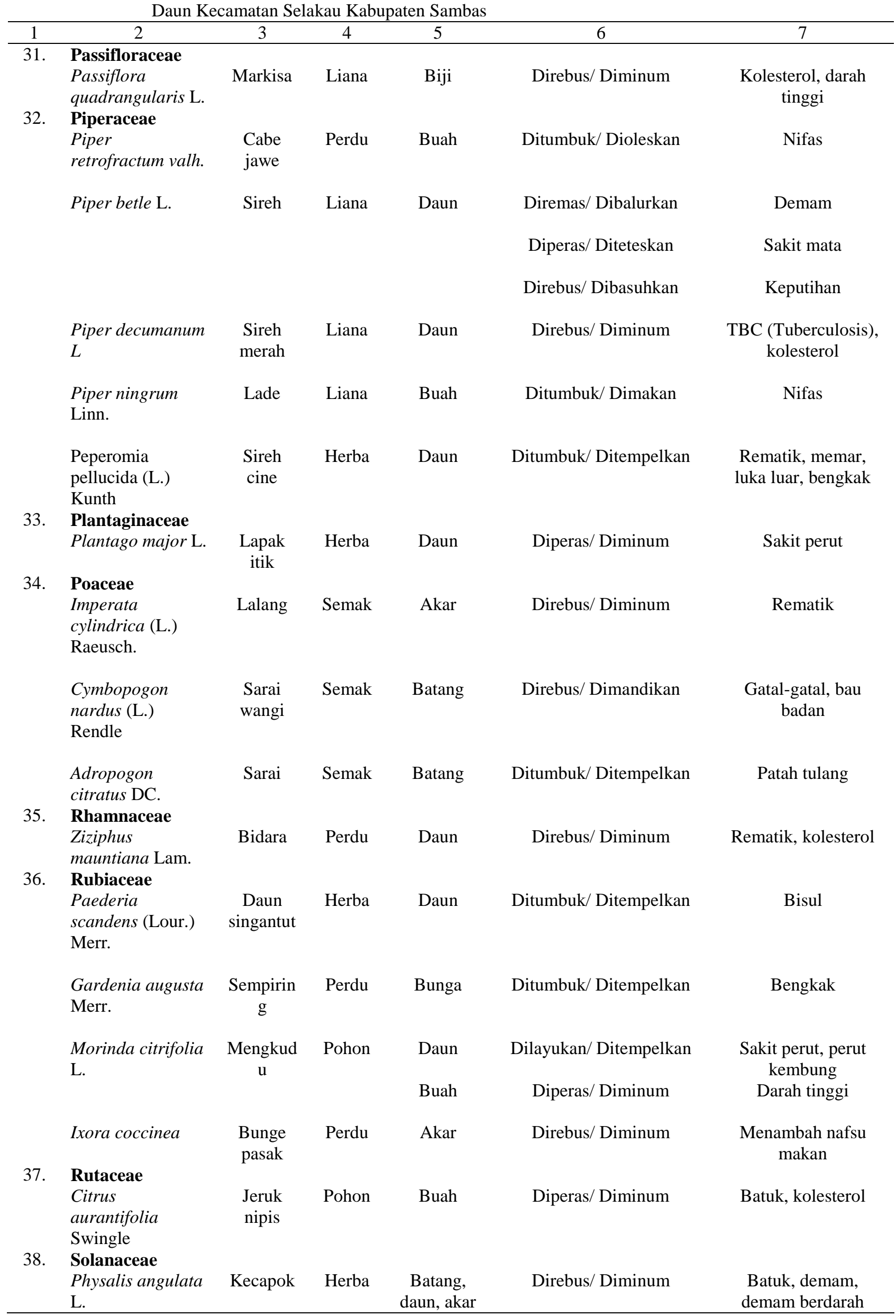


Lanjutan Tabel 1. Famili dan Jenis Tumbuhan Obat yang digunakan oleh Masyarakat Suku Melayu di Desa Sungai Daun Kecamatan Selakau Kabupaten Sambas

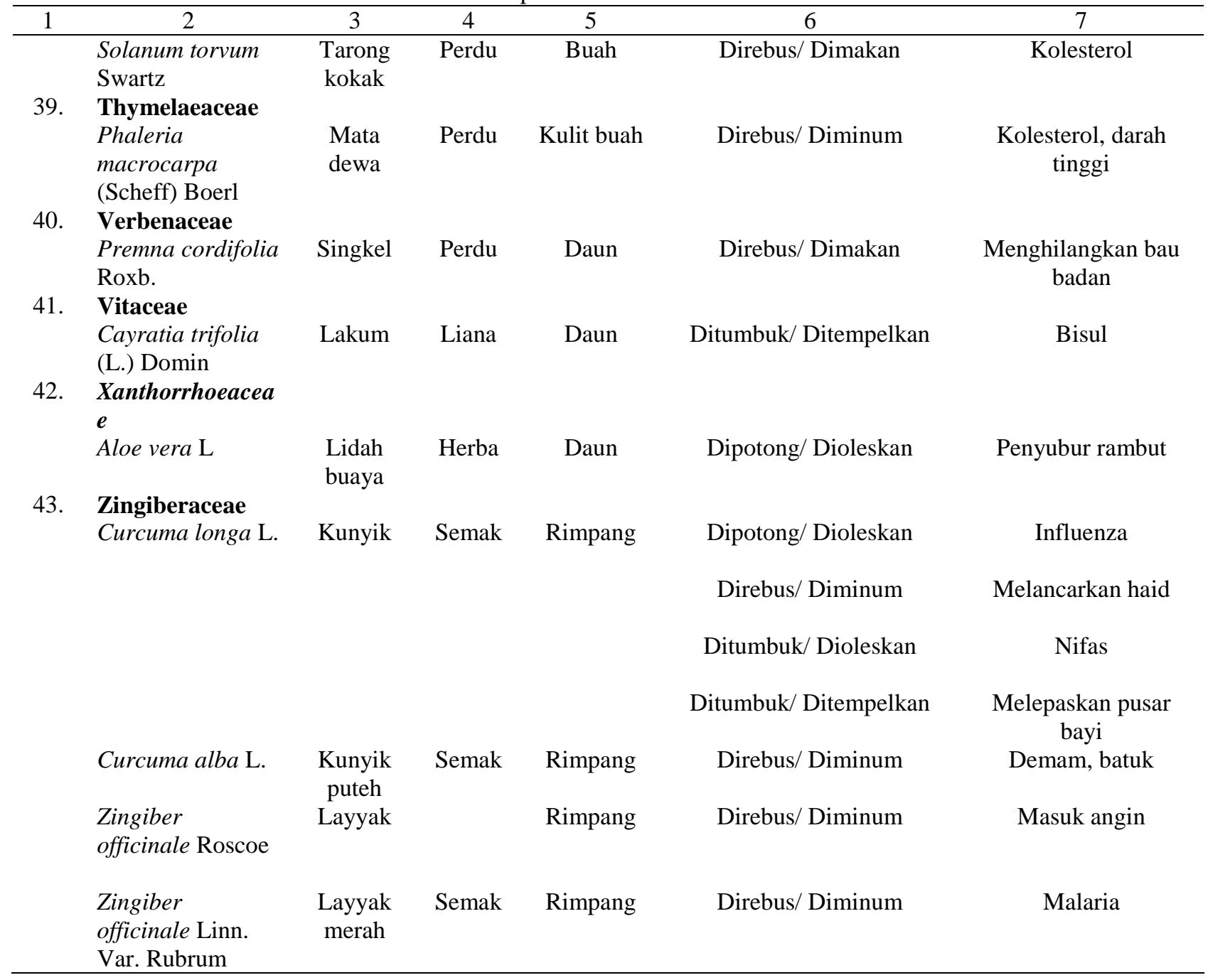

Persentase terbesar jenis tumbuhan yang diperoleh adalah Famili Asteraceae $(6,8 \%)$, Euphorbiaceae (6,8\%) dan Piperaceae (6,8\%), yang masingmasing terdiri atas 5 jenis tumbuhan. Persentase terkecil jenis tumbuhan yang diperoleh adalah famili Acanthaceae, Amaranthaceae, Annonaceae, Apocynaceae, Basellaceae, Campanulaceae, Caricaceae, Clusiaceae, Crassulaceae, Elaeocarpaceae, Iridaceae, Lauraceae, Marantaceae, Melastomataceae, Moraceae, Moringaceae, Musaceae, Oleaceae, Oxalidaceae, Pandanaceae, Passifloraceae, Plantaginaceae, Rhamnaceae, Rutaceae, Thymelaeaceae, Verbenaceae, Vitaceae, dan Xanthorrhoeaceae yang masing-masing terdiri atas 1 jenis tumbuhan (1,3) (Gambar 2).

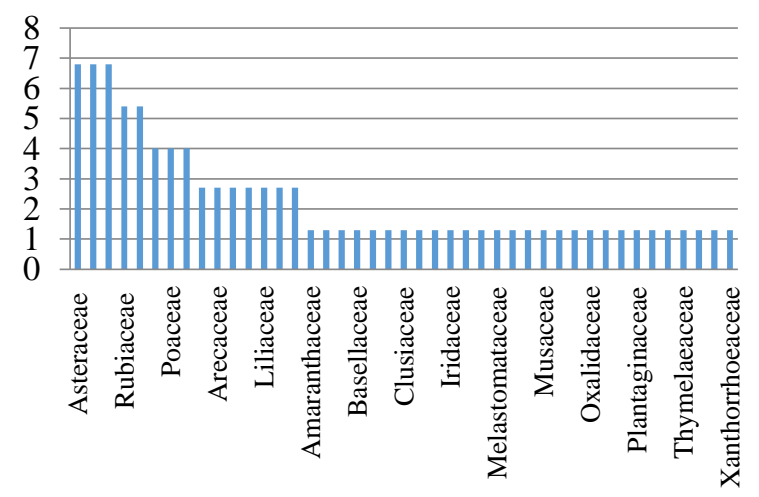

Gambar 2. Jenis Tumbuhan Obat Berdasarkan Famili

Persentase terbesar bagian tumbuhan yang dimanfaatkan sebagai obat oleh masyarakat Suku Melayu di Desa Sungai Daun adalah daun sebesar $48,8 \%$. Bagian tumbuhan yang memiliki manfaat terkecil yaitu bunga (7\%) dan akar (7\%) (Gambar $3)$. 


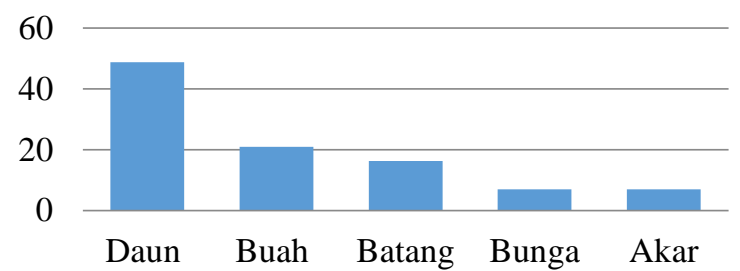

Gambar 3. Bagian Tumbuhan yang Digunakan sebagai Obat

Persentase terbesar cara penggunaan tumbuhan obat oleh masyarakat Suku Melayu di Desa Sungai Daun yaitu diminum (48,3\%), sedangkan persentase terkecil yaitu dibasuhkan $(1,1 \%)$ (Gambar 4).

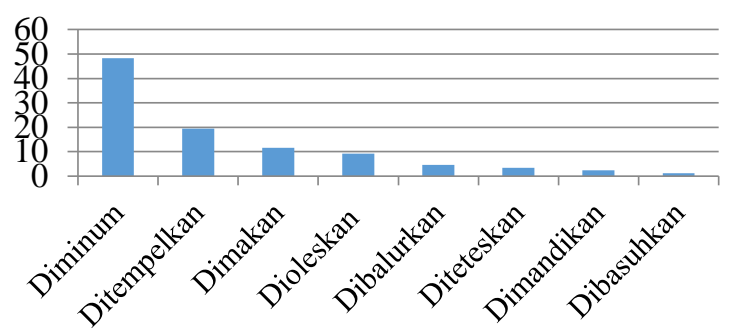

Gambar 4. Cara Penggunaan Tumbuhan Obat

Tumbuhan obat yang dimanfaatkan oleh masyarakat Suku Melayu di Desa Sungai Daun diambil dari beberapa tempat yaitu hutan, kebun, tepi jalan dan pekarangan rumah (Gambar 5). Persentase terbesar diperoleh di pekarangan rumah $(68,9 \%)$. Persentase terkecil tumbuhan obat diperoleh di hutan $(2,7 \%)$.

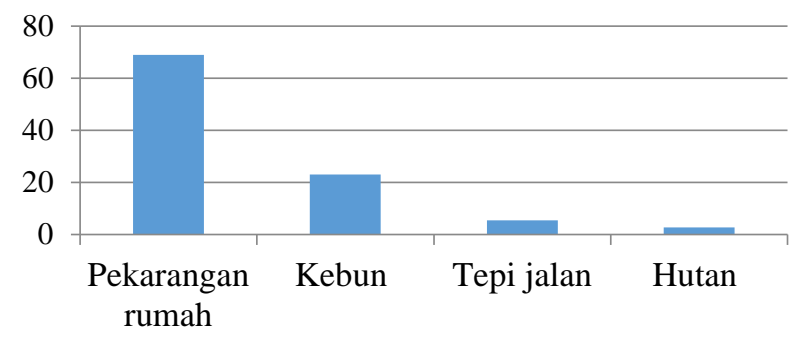

Gambar 5. Persentase Tempat Pengambilan Tumbuhan Obat

\section{Pembahasan}

Berdasarkan hasil penelitian jenis tumbuhan obat yang digunakan oleh masyarakat Suku Melayu di Desa Sungai Daun Kecamatan Selakau Kabupaten Sambas diperoleh 74 jenis tumbuhan yang termasuk ke dalam 43 famili. Jenis tumbuhan obat yang diperoleh lebih banyak dibandingkan dengan hasil penelitian Sudarmono (2018) yang menemukan 30 jenis tumbuhan obat dan 20 famili yang dimanfaatkan masyarakat di Sambas Botanical Garden. Keanekaragaman jenis dan famili tumbuhan obat di Desa Sungai Daun menggambarkan berbagai jenis tumbuhan dapat dijadikan bahan ramuan obat. Persentase jenis tumbuhan obat berdasarkan famili yang terbesar adalah Euphorbiaceae (6,8\%), Asteraceae (6,8\%), dan Piperaceae $(6,8 \%)$, yang masing-masing terdiri atas 5 jenis tumbuhan.

Famili Euphorbiaceae paling banyak ditemukan karena mudah tumbuh sehingga ditemukan di berbagai habitat. Menurut Djawarningsih (2012), Famili Euphorbiaceae memiliki masa pembungaan dan pembuahan sepanjang tahun serta sebarannya cukup luas di Indonesia. Jenisjenis tumbuhan Famili Euphorbiaceae yang dimanfaatkan masyarakat Suku Melayu di Desa Sungai Daun sebagai obat adalah puring, ekor kucing, bandong, meniran dan cangkok manis. Menurut Karyati \& Adhi (2018) berdasarkan jumlah spesies, Famili Asteraceae termasuk famili terbesar dan terbanyak dari famili tumbuhan berbunga (angiospermae). Jenis-jenis tumbuhan Famili Asteraceae yang digunakan sebagai obat yaitu bunge insulin, kedaraan, keniker, kalimao dan sambung nyawa. Famili Piperaceae merupakan tumbuhan yang umumnya digunakan masyarakat sebagai obat dan biasanya sengaja ditanam di pekarangan rumah dan kebun sehingga mudah untuk diperoleh. Jenis-jenis tumbuhan Famili Piperaceae yang digunakan sebagai obat adalah cabe jawe, sireh, sireh merah, lade dan sireh cine.

Bagian daun tumbuhan paling banyak digunakan karena daun mudah diperoleh dan selalu tersedia dibandingkan dengan bagian lainnya seperti bunga, buah dan biji. Penelitian oleh Wulandara et al (2018), di Desa Durian Sebatang diperoleh bagian daun tumbuhan paling banyak dimanfaatkan karena pengolahannya lebih mudah dan bisa juga dikeringkan agar tahan lama. Menurut Fakhrozi (2009) dalam Haryono et al (2014), daun adalah bagian tumbuhan yang paling banyak dimanfaatkan karena pemanfaatan pada daun tidak menimbulkan pengaruh besar terhadap pertumbuhan suatu spesies dibandingkan dengan batang atau akar dari tumbuhan tersebut dan tidak berdampak buruk bagi kelangsungan hidup tumbuhan.

Cara pengolahan tumbuhan obat oleh masyarakat di Desa Sungai Daun paling banyak adalah dengan cara direbus karena dianggap masyarakat sangat efektif, mudah dan mengeluarkan kandungan kimia lebih banyak. Menurut Gunadi et al (2017), proses perebusan dapat mengangkat zat yang terkandung pada tumbuhan dan mempunyai reaksi yang begitu cepat bila diminum dibandingkan dengan cara dikunyah, dibakar, 
ditempel maupun yang lainnya. Sesuai dengan Voight (1994) dalam Sari et al (2015) yang menyatakan bahwa semakin tinggi temperatur maka kelarutan suatu zat semakin besar. Cara penggunaan yang paling banyak dilakukan adalah diminum karena masyarakat setempat lebih sering mengolah tumbuhan obat dengan cara direbus dan air rebusannya diminum. Masyarakat juga percaya bahwa dengan cara diminum penyakit akan cepat sembuh. Hasil penelitian Haryono et al (2014), dengan cara diminum penyakit yang mereka rasakan akan sembuh dan mempunyai reaksi yang lebih cepat dibandingkan dengan cara dioles, ditempel maupun dengan cara lainnya.

Masyarakat Suku Melayu di Desa Sungai Daun meyakini bahwa masing-masing penyakit dapat disembuhkan oleh tumbuhan yang berbeda, tetapi ada juga tumbuhan yang dapat mengobati jenis penyakit lebih dari satu. Seperti tumbuhan kodok di Desa Sungai Daun untuk mengobati luka luar dan keracunan, sedangkan Suku Melayu di Dusun Serambi Kecamatan Kembayan Kabupaten Sanggau tumbuhan kodok untuk mengobati sakit perut dan turunkan tekanan darah tinggi (Sari et al., 2014). Tumbuhan gelembeng di Desa Sungai Daun untuk mengobati batuk dan darah tinggi, sedangkan Suku Dayak di Desa Kayu Tanam Kecamatan Mandor Kabupaten Landak tumbuhan gelembeng untuk mengobati malaria dan maag (Efremila et al., 2015). Tumbuhan jeruk nipis di Desa Sungai Daun untuk mengobati batuk dan kolesterol, sedangkan Desa Sejahtera Kecamatan Sukadana Kabupaten Kayong Utara tumbuhan jeruk nipis untuk melepaskan tali pusar bayi (Aminah et al., 2016). Adanya perbedaan pemanfaatan tumbuhan obat pada suatu daerah karena pengetahuan mengenai pemanfaatan tumbuhan obat merupakan warisan turun temurun dari leluhur yang berbeda sehingga kepercayaan terhadap manfaat tumbuhan yang digunakan sebagai obat juga berbeda.

Tumbuhan obat memiliki kandungan senyawa metabolit sekunder, sebagai contoh tumbuhan lakum memiliki kandungan senyawa metabolit sekunder seperti alkaloid, flavonoid dan tannin (Lestari et al., 2018). Tumbuhan ini dapat digunakan untuk mengobati bisul. Menurut Prasetyo et al (2016), penggunaan daun lakum dalam mengobati bisul bertujuan untuk mengecilkan bisul, mengurangi rasa nyeri dan membantu mencegah penyebaran bisul. Menurut Kusuma (2009) dalam Prasetyo et al (2016) menyatakan bahwa bisul merupakan penyakit infeksi yang disebabkan oleh bakteri Staphylococcus aureus. Menurut Gupta et al
(2012) dalam Lestari et al (2018) menyatakan bahwa senyawa metabolit sekunder yang terdapat pada tumbuhan lakum diketahui dapat digunakan antibakteri, Hasil penelitian Cruz et al (2014), ekstrak etanol daun lakum pada konsentarsi $75 \%$ dan $100 \%$ menghambat pertumbuhan bakteri Staphylococcus aureus sehingga daun lakum memiliki sifat antibakteri sebagai obat alternatif untuk bisul.

Tumbuhan obat yang digunakan oleh masyarakat Suku Melayu di Desa Sungai Daun paling banyak diambil langsung di pekarangan rumah karena sangat efektif bagi masyarakat memanfaatkan tumbuhan liar yang keberadaannya banyak di sekitar pekarangan rumah dan ada juga masyarakat yang menanam sendiri atau membudidayakan berbagai macam tumbuhan obat di pekarangan rumahnya agar mudah diperoleh bila dibutuhkan. Menurut Okakinanti (2014), tumbuhan obat yang dimanfaatkan oleh masyarakat Menyuke lebih banyak dijumpai di pekarangan rumah karena masyarakat memang sudah menanam sendiri berbagai macam tumbuhan obat di pekarangan rumahnya.

\section{DAFTAR PUSTAKA}

Ahyat, SI, 2005, Dinamika dan Pengaruh Budaya Melayu di Kalimantan Barat, International Conference on Indonesia Studies, Departemen Sejarah, Fakultas Ilmu Pengetahuan Budaya, Universitas Indonesia, Balai Pustaka, Jakarta

Aminah, S, Wardenaar, E, \& Muflihati, 2016, Tumbuhan Obat yang Dimanfaatkan oleh Battra di Desa Sejahtera Kecamatan Sukadana Kabupaten Kayong Utara, Jurnal Hutan Lestari, Vol. 4, No. 3, Hal: 299-305

Badan Pemberdayaan Masyarakat \& Pemerintahan Desa, 2014, Daftar Isian Potensi Desa dan Tingkat Perkembangan Desa, Pemerintah Kabupaten Sambas

Bernard, H, 2004, Research Methods in Antropology; Qualitative and Quantitative Method Third Edition, Almitra Press, Walnut Creek California

Cruz, PC, Jerold, CA, \& Jonas, PC, 2014, Antibacterial Property of Cayratia trifolia L. as an Alternative Treatment for Boils, The Internasional Journal Research Publication's, Vol. 12, No. 12

Dalimartha, S, 1999, Atlas Tumbuhan Obat Jilid 1, Trubus Agriwidya, Jakarta 
Djarwaningsih, 2012, Jenis-Jenis Euphorbiaceae (Jarak-Jarakan) yang berpotensi sebagai Obat Tradisional, Herbarium Bogoriense Bidang Botani Puslit Biologi, LIPI, Cibinong Science Centre

Efremila, Wardenaar, E, \& Sisilia, L, 2015, Studi Etnobotani Tumbuhan Obat oleh Etnis Suku Dayak di Desa Kayu Tanam Kecamatan Mandor Kabupaten Landak, Jurnal Hutan Lestari, Vol. 3, No. 2, Hal: 234-246

Gunadi, D, Oramahi, AH, \& Tavita, EG, 2017, Studi Tumbuhan Obat Pada Suku Dayak di Desa Gerantung Kecamatan Monterado Kabupaten Bengkayang, Jurnal Hutan Lestari, Vol. 5, No. 2, Hal: 425-436

Harada, K, Mulyati, R, \& Anwar, M, 2006, Tumbuhan Obat Taman Nasional Gunung Halimun Jawa Barat Indonesia, PALMedia

Haryono, D, Wardenaar, E, \& Yusro, F, 2014, Kajian Etnobotani Tumbuhan Obat di Desa Mengkiang, Kecamatan Sanggau Kapuas, Kabupaten Sanggau, Jurnal Hutan Lestari, Vol. 2, No.3

Indra, Husni, H, \& Sisilia, L, 2014, Kajian Etnobotani Tumbuhan Obat Etnis Melayu di Desa Sungai Baru dan Desa Sempadian Kabupaten Sambas, Jurnal Hutan Lestari, Vol. 2, No. 2

Karyati \& Adhi, MA, 2018, Jenis-Jenis Tumbuhan Bawah di Hutan Pendidikan Fakultas Kehutanan Universitas Mulawarman, Mulawarman Press, Samarinda

Kinho, J, Arini, DID, Tabba, S, Kama, H, Kafiar, Y, Shabri, S, \& Karundeng, CM, 2011, Tumbuhan Obat Tradisional di Sulawesi Utara Jilid I, Balai Penelitian Kehutanan Manado, Manado

Kinho, J, Arini, DID, Halawane, J, Nurani, L, Halidah, Kafiar, Y, \& Karundeng, CM, 2011, Tumbuhan Obat Tradisional di Sulawesi Utara Jilid II, Balai Penelitian Kehutanan Manado, Manado

Lestari, DF, Rusmiyanto, PWE, \& Kurniatuhadi, R, 2018, Daya Hambat Ekstrak Etanol Batang Lakum (Cayratia trifolia (L.) Domin) Terhadap Pertumbuhan Isolat Phytophthora sp. Im5 secara In Vitro, Jurnal Protobiont, Vol. 7, No. 3, Hal: $15-23$

Okakinanti, AE, 2014, Etnobotani Tumbuhan Obat di Manyuke dan Implementasinya dalam Pembuatan Buklet Manfaat Keanekaragaman Hayati, Skripsi, Program Studi Pendidikan Biologi FKIP Universitas Tanjungpura, Pontianak
Prasetyo, B, Linda, R, \& Mukarlina, 2016, Pemanfaatan Tumbuhan Lakum (Cayratia trifolia (L.) Domin.) oleh Etnis Melayu Kecamatan Sungai Kunyit Kabupaten Mempawah, Jurnal Protobiont, Vol. 5, No. 2, Hal: 25-33

Sari, YR, Wardenaar, E, \& Muflihati, 2014, Etnobotani Tumbuhan Obat di Dusun Serambi Kecamatan Kembayan Kabupaten Sanggau Kalimantan Barat, Jurnal Hutan Lestari, Vol. 2, No.3

Sari, A, Linda, R \& Lovadi, I, 2015, Pemanfaatan Tumbuhan Obat Pada Masyarakat Suku Dayak Jangkang Tanjung Di Desa Ribau Kecamatan Kapuas Kabupaten Sanggau, Jurnal Protobiont, Vol. 4, No. 2, Hal: 1-8

Sudarmono, 2018, Keanekaragaman Tanaman Obat di Sambas Botanical Garden Kalimantan Barat Indonesia, the Journal of Tropical Life Science, Vol. 8, No. 2, Hal: 116-122

Steenis, V, Hoed, Bloembergen, \& Eyma, 2005, Flora, PT, Pradnya Paramita, Jakarta

Wulandara, DF, Rafdinal, \& Linda, R, 2018, Etnobotani Tumbuhan Obat Suku Melayu Desa Durian Sebatang Kecamatan Seponti Kabupaten Kayong Utara, Jurnal Protobiont, Vol. 7, No. 3, Hal: 36-46 